\title{
Isolated Extra- Pontine Myelinolysis in Alcohol Withdrawal
}

\author{
Pallavi Abhilasha ${ }^{1}$, Mrinalini Reddy ${ }^{1}$, R. Arul Saravanan $^{1}$, \\ M. Thirunavukarasu ${ }^{1}$ \\ ${ }^{1}$ SRM Medical College \& Research Centre, Kattanakulathur, Tamil Nadu State, India
}

\begin{abstract}
Osmotic demyelination syndromes are often progressive disorders, with clinical features ranging from a mild tremor or dysarthria to a progressive quadriparesis. Although rapid correction of serum sodium is known to be a potent causative factor, additional pathogenic factors exist, which appear critical in predisposing pontine and extrapontine glia to osmotic stress. Interestingly, several cases of osmotic demyelination have emerged where serum sodium was found to be within normal limits and minimal or no correction of a hypo or hypernatraemic state was implemented. Here we report a case of isolated extra pontine myelinolysis during alcohol withdrawal state, with no sodium fluctuation.
\end{abstract}

Key Words: Alcohol, Pons, Central Pontine Myelinolysis, Extra Pontine Myelinolysis.

Copyright @ 2018 KBCSM, Zagreb

e-mail: alcoholism.kbcsm@gmail.com•www.http://apr.kbcsm.hr

\section{Introduction}

Central pontine myelinolysis (CPM), a potentially fatal and debilitating neurological condition, was first described in 1959 by Adams et al [1]. Involvement of the corticospinal tracts in the pons and midbrain, results in spastic quadriparesis and pseudobulbar palsy, is a characteristic neurological finding and renders this condition its name. Progressive lethargy, quadriparesis, dysarthria, ophthalmoplegia, and ataxia are some of the frequent manifestations of CPM. It

Correspondence to:

Dr. Arul Saravanan Ramachandran, MD, DPM

Associate Professor, Department of Psychiatry, SRM Medical

College \& Research Centre

SRM IST, Kattanakulathur, Kancheepuram District,

Tamil Nadu-603203

E-mail: arulpsg@gmail.com was later discovered that the process of osmotic demyelination was not confined exclusively to the pons but also involved various extrapontine sites, a condition referred to as extrapontine myelinolysis (EPM) [2]. EPM generally occurs along with CPM but may occur in isolation as well [3, 4]. Isolated Extra Pontine myelinolysis (EPM) was first described in a study on alcoholic and malnourished patients. Isolated EPM is relatively rare. Extrapyramidal features and myoclonus of EPM are some of the symptoms that represent potentially treatable manifestations of the disease and should be differentiated from CPM [1]. The term osmotic demyelination syndrome encompasses both the above mentioned entities. Comorbidities associated 
with higher incidence of EPM include dialysis, liver failure, liver transplantation, advanced lymphoma, carcinoma, cachexia, severe bacterial infections, acute hemorrhagic pancreatitis, chronic alcoholism, and pellagra $[5,6]$. Chronic alcoholism associated EPM tends to be benign with a favorable prognosis compared to EPM secondary to rapid correction of hyponatraemia. We report a case of isolated EPM due to alcohol withdrawal in a male patient without any specific electrolyte corrections.

\section{Case report}

A 46 year old male patient was admitted in our de-addiction unit with abrupt onset of tremors for the past 5 days. He gave history of consuming alcohol for the past 30 years, daily consumption for the past 25 years, with the amount of alcohol progressively increasing from $270 \mathrm{~mL}$ to $750 \mathrm{~mL}$ of brandy over the years. A week prior to current admission, he indulged in binge drinking. Following episodes of vomiting, poor food intake and generalized weakness, he consulted a GP who had put him on oral benzodiazepines and vitamins. As his condition did not improve, he presented to our OPD with complaints of loss of appetite, vomiting, tremors, poor sleep and weakness. He gave previous history of 2 failed de-addiction treatments elsewhere. There were no h/o seizures, head injury or hospitalization for mental illness, or drug use other than smoking. Past medical history showed right Carpel Tunnel Syndrome, managed conservatively.

Upon hospital admission, the patient was alert and well oriented. His cranial nerve examination was normal. Corse tremors of upper limbs were prominent. Muscle wasting noted on the small muscles of the right hand.
The power on all four limbs was 4/5. The deep tendon reflexes showed brisk response. Cerebellar testing revealed intact dysdiadochokinesia and finger-to-nose performance. The Romberg's sign was positive. The plantar reflex showed bilateral flexor response. The laboratory tests on admission revealed a normal blood cell count and normal serum electrolytes including serum sodium. The renal function was within the normal range.

He was put on detoxification regimen with oral chlordiazepoxide along with supportive vitamins and supplements. No parentral fluids or medications were given. During the first week of admission the patient showed improvement, however his tremors persisted. In the second week the patient's condition worsened. He had gradual yet progressive weakness of limbs to such a severity that he had to be fed by his wife and he was unable to even sit in the bed. His cranial nerve examination showed mild right upper motor facial palsy. Oro-buccal dyskinesia in the form of pouting and tongue protrusion was noted. Corse tremors of both limbs were prominent. The power on the right UL was $3 / 5$ and right LL was $4 / 5$. The deep tendon reflexes showed exaggerated response. Cerebellar signs were obviated by the severe tremors. The plantar reflex showed flexor response in the right and extensor response in the left. All along his sensorium was intact.

The laboratory tests for alcohol-induced brain injury, such as Wernicke encephalopathy or hepatic encephalopathy, were performed. All of these test results, including vitamins B1, B6, and B12, ammonia and serum ceruloplasmin were within normal limits. In view of worsening clinical picture a MRI brain was planned to rule out any evolving stroke.

MRI BRAIN scan (Fig. 1) showed high signal intensity on T2- Weighted FLAIR and 

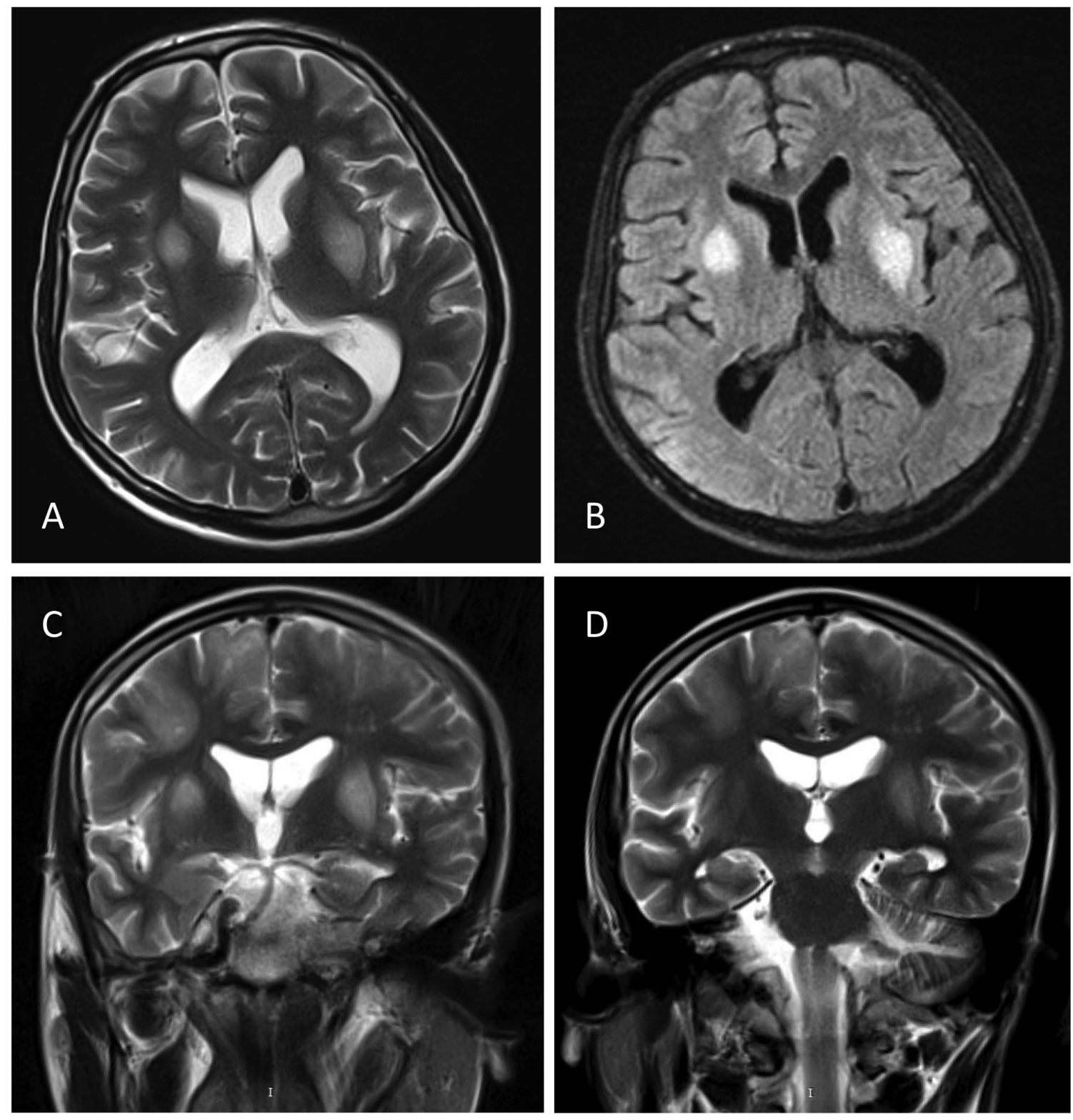

Figure 1 Magnetic Resonance Image of the Brain showing (A) T2 weighted axial image with hyperintensities in bilateral putamen and caudate nucleus; (B) T2 FLAIR axial image showing increased signal in bilateral putamen; (C) T2 coronal image showing increased signal in bilateral basal ganglia and frontal cortices; (D) T2 coronal image showing no involvement of the pons.

DWI sequence in bilateral lentiform nucleus, bilateral frontal lobe gyri, bilateral subcortical white matter in the frontal lobe and right middle cerebellar peduncle, with minimal diffusion restriction noted in these areas. There were no changes noted within the Pons. With 
this and the clinical picture, the diagnosis of 'Extra Pontine Myelinolysis' was clinched. He was managed conservatively with parentral Thiamine $100 \mathrm{mg}$ in $100 \mathrm{~mL}$ of normal saline for five days along with other neuroprotective drugs. His condition improved over the next two weeks, when he was able to walk with support and take food on his own, following which he was discharged with advice on neuro-rehabilitation.

\section{Discussion}

The most common cause of CPM and EPM in literature is a rapid correction of hyponatraemia. During prolonged hyponatraemia, the brain remains to be relatively isotonic with its surroundings by decreasing the intracellular levels of these osmolytes. When hyponatraemia is corrected with intravenous delivery of fluids, the extracellular tonicity increases, and this is followed by an increase in intracellular tonicity. However, if the serum sodium levels rise too rapidly and insufficient time is allowed for the brain to adjust to the new tonicity, the increased extracellular tonicity will cause osmolytes to continue moving out of brain cells into the extracellular space. This can lead to CPM or EPM, where the myelin sheath surrounding the nerve axons becomes damaged in certain parts of the brain [5]. Features of CPM were absent in our patient. There was no evidence of diminution in consciousness, 'locked in syndrome', tetraplegia, pseudobulbar palsy and the pons was uninvolved.

There are very few cases of isolated EPM reported and even rarer are those due to alcohol withdrawal. In these cases, the EPM may be unrelated to hyponatraemia or its correction $[6,7]$. It has been said that chronic alcoholics may not be able to maintain protective cerebral mechanisms against osmotic stress. The contribution of the effects of the direct toxicity of alcohol during the course of alcohol withdrawal is also considered important [5]. Preexisting malnutrition, hypoxia, comorbid drug misuse, Addison's disease, immunosuppression increase the risk of myelin damage.

The diagnosis of EPM is initially determined from clinical symptoms and is confirmed by magnetic resonance imaging of the brain [8]. EPM may manifest as postural limb tremors, myoclonic jerks, catatonia, dystonia or even pyramidal dysfunction. Findings supporting the diagnosis of EPM were the presence of tremors, reduced speech and orobuccal movements, as has been reported in another case with isolated EPM. Along with these our patient also had significant limb weakness to such a severity that an evolving stroke was considered. Magnetic resonance imaging is the imaging sequence of choice for the detection of EPM lesions [8]. Areas affected by myelinolysis are hypoattenuating and involving the basis pontis with sparing of pontine tegmentum in CPM. Whereas in EPM Basal ganglia, thalamus, cerebellum and sub cortical white matter are involved [9]. The MRI findings of hyperintense changes noted in bilateral lentiform nucleus, bilateral frontal lobe gyri, bilateral subcortical white matter in frontal lobe and right middle cerebellar peduncle in our case indicated a diagnosis of EPM.

Though isolated EPM, with no acute correction of hyponatraemia have been reported previously, they were seen only in chronic alcoholics with severe liver disease, Wernicke encephalopathy and with primary or secondary adrenal insufficiency [10]. None of these were present in our patient. 
Retrospectively, if we consider the fact that there was history of episodes of vomiting prior to admission, there could have been a possibility of hyponatraemia or a fluctuation in its level. There was the suspicion of whether the patient was given rapid correction of sodium by the GP. However the patient and wife denied having had any intravenous fluids treatment, which ruled out that possibility. CPM and EPM are poorly understood entities as there is no correlation between clinical signs and symptoms or in relation to neuroimaging.

Isolated case reports have shown some improvement with steroids or plasmapheresis. Patients may require neuro rehabilitation in most cases.

Previous reports have suggested that EPM from alcohol withdrawal has a better prognosis than EPM from a too rapid correction of hyponatraemia, as in our case [11]. This case is unique because it presented with EPM without CPM, did not have any acute correction of sodium and presented as evolving stroke.

\section{References}

1. Adams RD, Victor M, Mancall EL. Central pontine myelinolysis: a hitherto undescribed disease occurring in alcoholic and malnourished patients. AMA Arch Neurol Psychiatry. 1959 ;81:154-72.

2. Martin RJ. Central pontine and extrapontine myelinolysis: the osmotic demyelination syndromes. J Neurol Neurosurg Psychiatry. 2004;75:iii22-28.

3. Babanrao SA, Prahladan A, Kalidos K, Ramachandran K. Osmotic myelinolysis: Does extrapontine myelinolysis precede central pontine myelinolysis? Report of two cases and review of literature. Indian J Radiol Imaging. 2015;25:177-83.

\section{Conclusion}

This case describes a patient with worsening tremors and progressive motor weakness which could have been associated simply with alcohol withdrawal. However EPM was ultimately diagnosed by MRI examination. The case emphasizes on the importance of intensive diagnostic studies to make a correct diagnosis in cases of ADS when recovery is delayed or progressive worsening occurs. Moreover, a correct diagnosis of EPM would lead to proper rehabilitation programs which are critical for patients with EPM secondary to chronic alcoholism.

\section{Acknowledgement}

Dr. Premukar, Associate Professor, Department of Radiology, SRM MCH \& RC

\section{Conflict of Interest}

None to declare

4. Stetkarova I, Svobodova Z, Soltez J, Svatova J. Extrapontine myelinolysis manifested selectively by acute severe parkinsonian syndrome. Case Report. Neuroendocrinol Lett. 2016 Nov;37(6):415-8.

5. Kleinschmidt-Demasters BK, Rojiani AM, Filley CM. Central and extrapontine myelinolysis: then... and now. Journal of Neuropathology \& Experimental Neurology. 2006;65:1-1.

6. Huq S, Wong M, Chan HA, Crimmins D. Osmotic demyelination syndromes: central and extrapontine myelinolysis. J Clin Neurosci. 2007;14:684-8.

7. Kim JH, Kim SH, Jeong HJ, Sim YJ, Kim DK, Kim GC. Central Pontine Myelinolysis Induced by 
Alcohol Withdrawal: A Case Report. Ann Rehabil Med. 2017;41:148-52.

8. Yoon B, Shim YS, Chung SW. Central pontine and extrapontine myelinolysis after alcohol withdrawal. Alcohol Alcohol. 2008;43:647-9.

9. Mohammed AS, Boddu P, Yazdani DF. Clinical evolution of central pontine myelinolysis in a patient with alcohol withdrawal: a blurred clinical horizon. Case reports in medicine. 2016;2016.
10. Imam YZ, Saqqur M, Alhail H, Deleu D. Extrapontine myelinolysis-induced parkinsonism in a patient with adrenal crisis. Case reports in neurological medicine. 2012;2012.

11. Mochizuki H, Masaki T, Miyakawa T, Nakane J, Yokoyama A, Nakamura $\mathrm{Y}$, et al. Benign type of central pontine myelinolysis in alcoholism. J Neurol. 2003;250:1077-83.

\section{Izolirana ekstrapontina mijelinoliza u slučaju alkoholnog apstinencijskog sindroma}

Sažetak - Sindromi osmotske demijelinizacije su često progresivni poremećaji, s kliničkim značajkama koje mogu biti u rasponu od blagog tremora ili disartrije pa do progresivne kvadripareze. lako je brza korekcija serumskog natrija poznata kao značajan uzročni faktor, postoje i dodatni patogeni faktori, koji su kritični u predisponiranju neuroglije moždanog mosta i neuroglije oko moždanog mosta u odnosu na osmotski stres. Zanimljivo, nekoliko slučajeva osmotske demijelinacije se pojavilo gdje je serumski natrij bio u normalnim granicama i minimalna ili nikakva korekcija hipo ili hipermatrijematskog stanja nije implementirana. Ovdje izvještavamo o slučaju mijelinolize izoliranog područja oko moždanog mosta tijekom stanja povlačenja alkohola bez fluktuacije natrija.

Ključne riječi: alkohol, moždani most, mijelinoliza, komplikacije moždanog mosta 